Aquaculture

\title{
Metabolic and histologic responses of pacu (Piaractus mesopotamicus) fed diets supplemented with increasing concentrations of ractopamine
}

\author{
Mariana Martins Drumond ${ }^{1,2^{\star}}$, Luciana de Paula Naves ${ }^{3}$, Paula Adriane Perez Ribeiro ${ }^{4}$, Marinez \\ Moraes de Oliveira², Daniel Okamura², Anaise Emanuele Resende ${ }^{5}$, Vinicius de Souza \\ Cantarelli², Priscila Vieira Rosa ${ }^{2}$
}

\footnotetext{
${ }^{1}$ Centro Federal de Educação Tecnológica de Minas Gerais, Belo Horizonte, MG, Brasil.

2 Universidade Federal de Lavras, Departamento de Zootecnia, Lavras, MG, Brasil.

${ }^{3}$ Universidade José do Rosário Vellano, Faculdade de Agronomia, Alfenas, MG, Brasil.

${ }^{4}$ Universidade Federal de Minas Gerais, Departamento de Zootecnia, Belo Horizonte, MG, Brasil.

${ }^{5}$ Universidade Federal de Lavras, Departamento de Medicina Veterinária, Lavras, MG, Brasil.
}

\begin{abstract}
An experiment was conducted during 60 days with forty pacu males fed diets supplemented with increasing concentrations of ractopamine $\left(0.00,11.25,22.50,33.75\right.$, and $\left.45.00 \mathrm{mg} \mathrm{kg}^{-1}\right)$. Eight fish were evaluated for each experimental diet. Performance and survival rate of the fish were measured. At the end of the experiment, blood was collected to determine the levels of cortisol, triacylglycerol, and protein. Moreover, the liver was collected to determine the activities of glucose-6phosphate dehydrogenase and malic enzymes. The fillets were collected to determine chemical composition, and histologic cuts were analyzed to verify muscle growth and deposition of adipose tissue between muscle fibers. Increasing concentrations of dietary ractopamine did not change feed intake, fillet yield, fillet content of protein and ash, and frequency of relative distribution of muscle fibers. By increasing the dietary ractopamine concentration, the serum cortisol level was elevated. Ractopamine supplementation $\left(45.00 \mathrm{mg} \mathrm{kg}^{-1}\right)$ increased serum levels of triacylglycerol and protein and reduced the activity of hepatic lipogenic enzymes and the survival rate of the fish, probably in response to the high concentration of circulating cortisol. In addition, the higher level of ractopamine supplementation evaluated in this research impaired the weight gain and feed conversion. However, $11.25 \mathrm{mg} \mathrm{kg}^{-1}$ ractopamine reduced the ether extract level determined in the fillet and the fat deposition between muscle fibers, improving the nutritional quality of meat.
\end{abstract}

Key Words: beta-adrenergic agonist, enzyme, metabolism, stress

\section{Introduction}

Aquaculture is an activity of great importance and productive potential worldwide (FAO, 2014). In many countries of South America, such as in Brazil, the captive production of tropical native fish is increasing and pacu (Piaractus mesopotamicus, Holmberg, 1887) is one of the species of interest (Boscolo et al., 2011; Barbieri and Bondioli, 2015; Venturini et al., 2015). Pacu has great potential for intensive fish farming because of its basic management, good growth rates, and relatively easy artificial reproduction (Jomori et al., 2005). However, pacu has a higher content of body fat mainly in the finishing rearing phase (Bicudo et al., 2010). As this is an undesirable

Received: July 6, 2016

Accepted: February 22, 2018

*Corresponding author: mmdrumond@gmail.com

Copyright (c) 2018 Sociedade Brasileira de Zootecnia. This is an Open Access article distributed under the terms of the Creative Commons Attribution License (http://creativecommons.org/licenses/by/4.0/), which permits unrestricted use, distribution, and reproduction in any medium, provided the original work is properly cited. feature by most consumers, it is necessary to establish strategies to reduce fat deposition in the carcasses of $P$. mesopotamicus (Oliveira et al., 2014).

Ractopamine is a beta-adrenergic agonist that alters nutrient metabolism and may promote greater muscle protein deposition, reducing fat content in the carcass (Ferreira et al., 2013). For pigs and cattle, ractopamine use as a feed additive is authorized in countries such as Brazil, United States, Canada, and South Korea (Niño et al., 2017), and there are many studies reporting that dietary ractopamine improves meat quality and animal performance (Andretta et al., 2012; Boler et al., 2012; Gerlemann et al., 2014; Kill et al., 2015). However, the European Union, China, Taiwan, and Russia have banned the use of this substance based on the lack of conclusive results on their safety for animal and human health (Niño et al., 2017). As there is no global consensus on ractopamine use in meat production, the scientific community needs to generate more information about the safety and animal performance effectiveness of this beta-adrenergic agonist. In this context, there are few studies about the use of ractopamine 
in diets for pacu (Bicudo et al., 2012; Oliveira et al., 2014), signaling the need for further work in this area.

The effect of ractopamine on the animal metabolism occurs by its binding to specific $\beta$-adrenergic receptors; however, the body responses can be influenced by the concentration and duration of the dietary ractopamine (Edmonds and Baker, 2010). Previous reports regarding effects of ractopamine on muscle growth in fish are contradictory (Haji-abadi et al., 2010; Bicudo et al., 2012; Devens et al., 2012), and none evaluated the hyperplasic and hypertrophic growth of pacu fed diets supplemented with ractopamine. Moreover, it is still controversial whether ractopamine reduces fat in the carcass due to lipogenesis inhibition or by lipolysis stimulation (Ferreira et al., 2013). Therefore, this study was conducted with pacu in the finishing phase to determine the effects of diets supplemented with increasing concentrations of ractopamine on performance, survival rate, serum parameters, and specific activity of hepatic lipogenic enzymes, as well as the yield, chemical composition, and histologic parameters of their fillets.

\section{Material and Methods}

Forty P. mesopotamicus were randomly distributed into five dietary treatments; therefore, eight fish were evaluated for each experimental diet. Each tank housed one fish for a total period of 70 days. For the first 10 days, the fish were fed a basal diet to allow them to adapt to the working environment; for the remaining 60 days, the fish received the experimental diets. Initially, one basal diet without ractopamine was formulated to meet the nutritional requirements of pacu in the finishing phase (Table 1) in accordance with Boscolo et al. (2011), except for the crude protein level which was increased to $312.8 \mathrm{~g} \mathrm{~kg}^{-1}$ because animals fed diet containing ractopamine can exhibit increased protein synthesis (Mitchell et al., 1990). This basal diet was then supplemented with four increasing concentrations of ractopamine $(11.25,22.50,33.75$, and $45.00 \mathrm{mg} \mathrm{kg}{ }^{-1}$ ) (Ractosuin ${ }^{\circledR}$, OuroFino Animal Health, Cravinhos, São Paulo, Brazil).

All five diets were then pelleted (industrial pelletizer CPM $2000^{\circledR}$, São Paulo, Brazil), dried in a forced-ventilation oven $\left(40{ }^{\circ} \mathrm{C} ; 24 \mathrm{~h}\right)$, hermetically packed in black plastic bags, and stored at $-18{ }^{\circ} \mathrm{C}$ until use. Throughout the study, the diets were provided until apparent satiation twice a day (08.00 and $16.00 \mathrm{~h}$ ). Each day, the tanks were siphoned $30 \mathrm{~min}$ after the end of the first feeding.

The experiment was conducted in accordance with ethical and animal welfare guidelines, and was carried out in Lavras, Minas Gerais, Brazil (-21 ${ }^{\circ} 14^{\prime} 43^{\prime \prime}$ latitude, $-44^{\circ} 59^{\prime} 59^{\prime \prime}$ longitude, and $919 \mathrm{~m}$ altitude). Forty males of P. mesopotamicus were obtained from commercial fish farm, each weighing $864.0 \pm 75.0 \mathrm{~g}$ and with approximately one year of age. They were maintained in an experimental station containing 40 glass tanks of $100 \mathrm{~L}$ volume each, arranged in a water recirculation system equipped with sand, ultraviolet, and biologic filters. Water quality parameters, including $\mathrm{pH}$ (6.92 \pm 0.18$)$, dissolved oxygen $\left(5.73 \pm 0.49 \mathrm{mg} \mathrm{L}^{-1}\right)$, ammonia $\left(0.0007 \pm 0.0002 \mathrm{mg} \mathrm{L}^{-1}\right)$, nitrite $\left(0.089 \pm 0.007 \mathrm{mg} \mathrm{L}^{-1}\right)$, and temperature $\left(27.6 \pm 0.2{ }^{\circ} \mathrm{C}\right)$, were monitored regularly and remained within acceptable values for pacu (Urbinati and Gonçalves, 2005). Fish were maintained under photoperiod of $12 \mathrm{~h}$ light: $12 \mathrm{~h}$ dark.

The survival rate was calculated considering the number of fish that died during the experimental period. Apparent feed intake for each pacu was recorded daily, in a dry matter basis, subtracting the weight of the container with feed before and after feeding. For weight gain calculations, the fish were weighed in the first and last experimental days. Feed conversion ratio was calculated by dividing feed intake by body weight gain.

At the end of the experimental period, the fish were fasted for $24 \mathrm{~h}$, captured from the tanks using a trawl, and then blood samples were collected by puncture of the tail vein using Vacutainer ${ }^{\circledR}$ tubes without anticoagulant. After blood collection, the pacu were anesthetized with benzocaine (Pharmasys, Piracicaba, SP, Brazil) $\left(150 \mathrm{mg} \mathrm{L}^{-1}\right)$,

Table 1 - Ingredients and nutritional composition of the basal diet without ractopamine

\begin{tabular}{|c|c|}
\hline Item & \\
\hline Ingredient ( $\mathrm{g} \mathrm{kg}^{-1}$ as fed bas & \\
\hline Soybean meal $(45 \% \mathrm{CP})$ & 405.0 \\
\hline Corn & 348.8 \\
\hline Fish meal & 80.0 \\
\hline Wheat meal & 80.0 \\
\hline Soybean oil & 35.2 \\
\hline Bicalcium phosphate & 38.0 \\
\hline Ascorbic acid & 0.6 \\
\hline Vitamin and mineral mix ${ }^{1}$ & 5.0 \\
\hline Butylated hydroxytoluene & 0.2 \\
\hline Salt & 2.0 \\
\hline L-lysine HCL & 1.9 \\
\hline DL-methionine & 2.8 \\
\hline L-threonine & 0.5 \\
\hline Nutritional composition (as- & \\
\hline Gross energy $\left(\mathrm{MJ} \mathrm{kg}^{-1}\right)$ & 17.2 \\
\hline Crude protein $\left(\mathrm{g} \mathrm{kg}^{-1}\right)$ & 312.8 \\
\hline Ether extract $\left(\mathrm{g} \mathrm{kg}^{-1}\right)$ & 70.8 \\
\hline $\begin{array}{l}\text { CP - crude protein. } \\
\text { }{ }^{2} \text { Vitamin and mineral mix (To } \\
\text { Quantity per kg of diet: vitan } \\
20 \mathrm{mg} \text {; vitamin B2, } 15 \mathrm{mg} \text {; vi } \\
120 \mathrm{mg} \text {; choline, } 2000 \mathrm{mg} \text {; } \\
80 \mathrm{mg} \text {; iodine, } 3 \mathrm{mg} \text {; Fe, } 24 \\
\text { hydroxytoluene, } 170 \mathrm{mg} \text {. }\end{array}$ & $\begin{array}{l}\text { orações, MG, Brazil). } \\
1000 \mathrm{IU} \text {; vitamin B1, } \\
\text { E, } 25 \mathrm{mg} \text {; vitamin PP, } \\
\text { folic acid, } 2 \mathrm{mg} \text {; Mn, } \\
\text { Se, } 0.10 \mathrm{mg} \text {; butylated }\end{array}$ \\
\hline
\end{tabular}


slaughtered, eviscerated discarding the skin with scales and the head, and weighed. During the evisceration procedure, the liver was collected and immediately frozen in liquid nitrogen. Additionally, the fillets were collected, weighed for calculation of the fillet yield (weight fillet/fish weight $\times 100$ ), and stored at $-20^{\circ} \mathrm{C}$ until chemical analysis.

The blood samples were centrifuged $(1372 \times g$ for 15 min) and the serum was collected to determine cortisol level $\left(\mu \mathrm{g} \mathrm{dL}^{-1}\right)$ by an enzyme immunoassay kit (Diagnostics Biochem Canada Inc., Canada, Catalog number CAN-C-270) as well as the levels of triacylglycerols $\left(\mathrm{mg} \mathrm{dL}^{-1}\right)$ and total protein $\left(\mathrm{g} \mathrm{dL}^{-1}\right)$ using standard commercial colorimetric kits (Labtest Diagnóstica SA, Lagoa Santa, Minas Gerais, Brazil, Catalog numbers of 87 for triacylglycerols and 99 for total protein).

Hepatic extracts $(0.1 \mathrm{~g}$ of liver for $1.2 \mathrm{~mL}$ of $25 \mathrm{mM}$ HEPES-KOH buffer; $p H$ 7.2) were obtained according to methodology described by Ribeiro et al. (2013) and were used to determine the catalytic activity of the glucose-6-phosphate dehydrogenase (EC1.1.1.49) and malic enzymes (EC1.1.1.40). The protein contents in the hepatic extracts $\left(\mathrm{g} \mathrm{mL}^{-1}\right)$ were measured according to the method of Bradford (1976) using bovine serum albumin as a standard to allow the calculation of the specific activity of the evaluated enzymes. Glucose-6-phosphate dehydrogenase activity was measured according to Graeve (1994) and expressed as $\mathrm{U} \mathrm{mg}^{-1}$ protein (since $1 \mathrm{U}$ corresponds to $1 \mu \mathrm{mol}$ of 6 -phospho-D-gluconate released during $1 \mathrm{~s}$ of reaction at $\mathrm{pH} 7.2$ and temperature of $25^{\circ} \mathrm{C}$ ). Malic enzyme activity was determined according to Spina Junior et al. (1970) and expressed as $\mathrm{U} \mathrm{mg}^{-1}$ protein (since $1 \mathrm{U}$ corresponds to $1 \mu \mathrm{mol}$ of pyruvate released during $1 \mathrm{~s}$ of reaction at $\mathrm{pH} 7.2$ and temperature of $25^{\circ} \mathrm{C}$ ).

Fillet samples were used to determine the levels of crude protein (Kjeldahl method; $\mathrm{N} x$ 6.25), ether extract (Soxhlet method), ash (gravimetric method), and moisture (gravimetric method) according to standard procedures of the AOAC (1990). In addition, white muscle aliquots of the dorsal region $(8 \times 4 \times 4 \mathrm{~mm})$ of each fish were collected and immediately fixed in modified Karnovsky's solution during $24 \mathrm{~h}$, without any previous freezing of the tissues. Karnovsky's solution consisted of $2.5 \%$ glutaraldehyde and $2 \%$ formaldehyde in $0.1 \mathrm{M}$ sodium phosphate buffer, $\mathrm{pH}$ 7.4. After fixation, the samples were dehydrated and encased in plastic resin. Resin blocks were then cut in sections of $4 \mu \mathrm{m}$ using a microtome (Leica Biossystem, Germany). Histological cuts were stained with hematoxylin and eosin and utilized to verify the type of muscle growth (hyperplasia and/or hypertrophy) and the amount of adipose tissue deposited between muscle fibers. Stained sections were analyzed via optical microscopy (model CX31, Olympus, Japan), at 10x magnification, coupled to a digital camera (Altramodel SC30, Olympus, Japan). Diameters of 200 muscle fibers were measured for each cut, according to Dubowitz et al. (2013), using the software of morphometric analysis SIS Cell B (Olympus, Japan). Afterwards, the muscle fibers were classified according their diameters $(<30 \mu \mathrm{m}$, between 30 and $50 \mu \mathrm{m},>50 \mu \mathrm{m})$ (Almeida et al., 2008) to aid in understanding the muscle growth. For determination of adipose tissue deposited between muscle fibers, 1564 intersections for each histological cut were evaluated using the software Image J (Wayne Rasband, National Institutes of Health, Bethesda, MD).

Initially, all data were checked by a normality test (Shapiro-Wilk). Normality of the data was confirmed for the apparent performance, survival rate, serum parameters, and specific activity of the hepatic enzymes, in addition to yield and chemical composition of fillets. These data were then subjected to analysis of variance using the General Linear Model of the statistical software SAS (Statistical Analysis System, version 9.4), and when significant, the means were compared with each other by the Student-Newman-Keuls test $(\mathrm{P}<0.05)$. However, data related to muscle growth and deposition of adipose tissue between muscle fibers showed non-normal distribution. Therefore, they were subjected to the non-parametric Kruskal-Wallis test $(\mathrm{P}<0.05)$, and when significant, the data were subjected to the multiple comparison Nemenyi test $(\mathrm{P}<0.05)$.

\section{Results}

Two fish that received the feed supplemented with $45.00 \mathrm{mg} \mathrm{kg} \mathrm{kg}^{-1}$ ractopamine died and, therefore, this treatment resulted in the smaller survival rate (Table 2). All the experimental diets were well accepted by the fish. The five diets evaluated did not change $(\mathrm{P}>0.05)$ the apparent feed intake measured during the 60 experimental days $(632.08 \pm 12.68 \mathrm{~g})$. However, the higher level of ractopamine supplementation evaluated in this research impaired the weight gain and the feed conversion.

The blood parameters and the catalytic activity of the hepatic lipogenic enzymes were influenced $(\mathrm{P}<0.05)$ by the dietary ractopamine level (Table 3 ). In general, serum cortisol content gradually increased $(\mathrm{P}<0.05)$ with the increasing concentrations of dietary ractopamine. When compared with the animals fed basal diet without ractopamine, the fish fed the diet supplemented with $45.00 \mathrm{mg} \mathrm{kg}^{-1}$ ractopamine showed a relative increase of $124 \%$ in the circulating cortisol content. Furthermore, the fish fed diet containing $45.00 \mathrm{mg}$ ractopamine per $\mathrm{kg}$ showed higher serum concentrations of 
triacylglycerols and total protein, representing a relative increase of approximately 97 and 36\%, respectively, compared with pacu fed the control diet. The maximum concentration of ractopamine evaluated in this study also reduced the specific activity of the glucose-6-phosphate dehydrogenase and malic enzymes in approximately 28 and $62 \%$, respectively.

The dietary ractopamine concentration did not affect $(\mathrm{P}>0.05)$ the fillet yield $\left(456.7 \pm 7.1 \mathrm{~g} \mathrm{~kg}^{-1}\right)$ or $(\mathrm{P}>0.05)$ the levels of crude protein $\left(230.7 \pm 14.2 \mathrm{~g} \mathrm{~kg}^{-1}\right)$ and ash $\left(13.3 \pm 0.4 \mathrm{~g} \mathrm{~kg}^{-1}\right)$ determined in the fillets (Table 4). However, the lowest $(\mathrm{P}<0.05)$ ether extract content and highest $(\mathrm{P}<0.05)$ moisture content were measured in fillet from pacu fed diet containing $11.25 \mathrm{mg} \mathrm{kg}^{-1}$ ractopamine.

The frequency of relative distribution of the muscle fibers in pacu, according to their diameter, was similar $(\mathrm{P}>0.05)$ for all dietary ractopamine concentrations. In general, there was a predominance of muscle fibers with diameters greater than $50 \mu \mathrm{m}(64.6 \pm 2.7 \%)$, followed by fibers with diameters between 30 and $50 \mu \mathrm{m}(25.8 \pm 1.6 \%)$, with the fewest fibers having diameters less than $30 \mu \mathrm{m}$ $(9.6 \pm 1.9 \%)$ (Table 5). The diet supplemented with $11.25 \mathrm{mg} \mathrm{kg}^{-1}$ ractopamine resulted in reduced $(\mathrm{P}<0.05)$ fat deposition between the muscle fibers of P. mesopotamicus in finishing phase, which can be observed in the photographic images referring to the histological sections of muscle tissue (Figure 1).

\section{Discussion}

The two fish that died were of the dietary treatment containing $45.00 \mathrm{mg}$ of ractopamine per $\mathrm{kg}$ of feed. In addition, this dietary treatment impaired the weight gain and the feed conversion of the fish, representing an important indication that this level of ractopamine inclusion is very high and should not be used for pacu.

Table 2 - Performance and survival rates of Piaractus mesopotamicus fed diets supplemented with increasing concentrations of ractopamine during the 60 experimental days

\begin{tabular}{|c|c|c|c|c|}
\hline Dietary ractopamine supplementation $\left(\mathrm{mg} \mathrm{kg}^{-1}\right)$ & $\begin{array}{c}\text { Survival rate } \\
(\%)^{1}\end{array}$ & $\begin{array}{c}\text { Apparent feed intake } \\
\text { (g per fish) }\end{array}$ & $\begin{array}{l}\text { Weight gain } \\
\text { (g per fish) }\end{array}$ & $\begin{array}{c}\text { Feed conversion } \\
\text { (g:g) }\end{array}$ \\
\hline 0.00 & $100 \mathrm{a}$ & $648.63 \mathrm{a}$ & $108.25 \mathrm{a}$ & $5.99 b$ \\
\hline 11.25 & $100 \mathrm{a}$ & $626.88 \mathrm{a}$ & $107.25 \mathrm{a}$ & $5.85 b$ \\
\hline 22.50 & $100 \mathrm{a}$ & $625.25 \mathrm{a}$ & $108.13 \mathrm{a}$ & $5.78 b$ \\
\hline 33.75 & $100 \mathrm{a}$ & $639.50 \mathrm{a}$ & $110.25 \mathrm{a}$ & $5.80 \mathrm{~b}$ \\
\hline 45.00 & $75 b$ & $630.15 a$ & $94.63 b$ & $6.66 \mathrm{a}$ \\
\hline Coefficient of variation ( $\%)$ & 13.34 & 8.74 & 7.66 & 7.98 \\
\hline
\end{tabular}

${ }^{1}$ Eight fish were evaluated for each experimental diet.

Means with different letters in the same column are significantly different from each other $(\mathrm{P}<0.05)$ by the Student-Newman-Keuls test.

Table 3 - Serum levels of cortisol, triacylglycerol, and total protein and activity of lipogenic enzymes in liver extracts of Piaractus mesopotamicus fed diets supplemented with increasing concentrations of ractopamine

\begin{tabular}{|c|c|c|c|c|c|}
\hline Dietary ractopamine supplementation $\left(\mathrm{mg} \mathrm{kg}^{-1}\right)$ & $\begin{array}{l}\text { Cortisol } \\
\left(\mu \mathrm{g} \mathrm{dL}^{-1}\right)\end{array}$ & $\begin{array}{l}\text { Triacylglycerol } \\
\qquad\left(\mathrm{mg} \mathrm{dL}^{-1}\right)\end{array}$ & $\begin{array}{l}\text { Total protein } \\
\qquad\left(\mathrm{g} \mathrm{dL}^{-1}\right)\end{array}$ & $\begin{array}{c}\text { G6PD } \\
\left(\mathrm{U} \mathrm{mg}^{-1} \text { protein }\right)^{1}\end{array}$ & $\begin{array}{c}\text { Malic enzyme } \\
\left(\mathrm{U} \mathrm{mg}^{-1} \text { protein }\right)^{2}\end{array}$ \\
\hline 0.00 & $3.27 \mathrm{c}$ & $307.41 b$ & $4.78 b$ & $1.74 \mathrm{a}$ & $0.26 \mathrm{a}$ \\
\hline 11.25 & $3.60 \mathrm{c}$ & $262.96 b$ & $5.05 \mathrm{~b}$ & $1.82 \mathrm{a}$ & $0.24 \mathrm{a}$ \\
\hline 22.50 & $4.52 \mathrm{bc}$ & $329.01 b$ & $5.23 b$ & $1.71 \mathrm{a}$ & $0.21 \mathrm{a}$ \\
\hline 33.75 & $5.17 \mathrm{~b}$ & $493.21 \mathrm{ab}$ & $5.01 \mathrm{~b}$ & $2.00 \mathrm{a}$ & $0.25 \mathrm{a}$ \\
\hline 45.00 & $7.33 \mathrm{a}$ & $606.17 \mathrm{a}$ & $6.52 \mathrm{a}$ & $1.27 \mathrm{~b}$ & $0.10 \mathrm{~b}$ \\
\hline Coefficient of variation (\%) & 16.12 & 20.96 & 10.00 & 14.08 & 11.82 \\
\hline
\end{tabular}

${ }^{1}$ Glucose-6-phosphate dehydrogenase activity was expressed as $\mathrm{U} \mathrm{mg}^{-1}$ protein, in which $1 \mathrm{U}$ corresponds to $1 \mu \mathrm{mol}$ of 6-phospho-D-gluconate released during $1 \mathrm{~s}$ of reaction.

${ }^{2}$ Malic enzyme activity was expressed as $\mathrm{U} \mathrm{mg}^{-1}$ protein, in which $1 \mathrm{U}$ corresponds to $1 \mu \mathrm{mol}$ of pyruvate released during $1 \mathrm{~s}$ of reaction.

Means with different letters in the same column are significantly different from each other $(\mathrm{P}<0.05)$ by the Student-Newman-Keuls test.

Table 4 - Yield and chemical composition determined in the fillets of Piaractus mesopotamicus fed diets supplemented with ractopamine at increasing concentrations

\begin{tabular}{|c|c|c|c|c|c|}
\hline Dietary ractopamine supplementation $\left(\mathrm{mg} \mathrm{kg}^{-1}\right)$ & $\begin{array}{l}\text { Fillet yield } \\
\qquad\left(\mathrm{g} \mathrm{kg}^{-1}\right)\end{array}$ & $\begin{array}{l}\text { Crude protein } \\
\qquad\left(\mathrm{g} \mathrm{kg}^{-1}\right)\end{array}$ & $\begin{array}{c}\text { Ash } \\
\left(\mathrm{g} \mathrm{kg}^{-1}\right)\end{array}$ & $\begin{array}{l}\text { Ether extract } \\
\qquad\left(\mathrm{g} \mathrm{kg}^{-1}\right)\end{array}$ & $\begin{array}{c}\text { Moisture } \\
\left(\mathrm{g} \mathrm{kg}^{-1}\right)\end{array}$ \\
\hline 0.00 & $44.84 \mathrm{a}$ & $25.37 \mathrm{a}$ & $1.29 \mathrm{a}$ & $65.10 \mathrm{a}$ & $668.30 \mathrm{~b}$ \\
\hline 11.25 & $44.98 \mathrm{a}$ & $21.92 \mathrm{a}$ & $1.35 \mathrm{a}$ & $34.00 \mathrm{~b}$ & $733.30 \mathrm{a}$ \\
\hline 22.50 & $45.98 \mathrm{a}$ & $22.96 \mathrm{a}$ & $1.32 \mathrm{a}$ & $55.20 \mathrm{a}$ & $702.00 \mathrm{ab}$ \\
\hline 33.75 & $46.32 \mathrm{a}$ & $23.25 \mathrm{a}$ & $1.40 \mathrm{a}$ & $52.50 \mathrm{a}$ & $701.00 \mathrm{ab}$ \\
\hline 45.00 & $46.24 \mathrm{a}$ & $21.87 \mathrm{a}$ & $1.31 \mathrm{a}$ & $61.90 \mathrm{a}$ & $706.30 \mathrm{ab}$ \\
\hline Coefficient of variation ( $\%)$ & 3.90 & 19.50 & 17.30 & 19.67 & 2.87 \\
\hline
\end{tabular}

Means with different letters in the same column are significantly different from each other $(\mathrm{P}<0.05)$ by the Student-Newman-Keuls test. 
Table 5 - Frequency of relative distribution of the white muscle fibers and deposition of adipose tissue between muscle fibers of Piaractus mesopotamicus fed diets supplemented with increasing concentrations of ractopamine

\begin{tabular}{|c|c|c|c|c|c|}
\hline \multirow{2}{*}{$\begin{array}{l}\text { Dietary ractopamine supplementation } \\
\left(\mathrm{mg} \mathrm{kg}^{-1}\right)\end{array}$} & \multicolumn{3}{|c|}{$\%$ of fibers according to their diameter } & \multirow{2}{*}{$\begin{array}{c}\text { Adipose tissue determined } \\
\text { in the histological cuts } \\
(\%)^{1}\end{array}$} & \multirow{2}{*}{$\begin{array}{c}\text { Muscle tissue determined } \\
\text { in the histological cuts } \\
(\%)^{1}\end{array}$} \\
\hline & $<30 \mu \mathrm{m}$ & 30 a $50 \mu \mathrm{m}$ & $>50 \mu \mathrm{m}$ & & \\
\hline 0.00 & $9.2 \mathrm{a}$ & $24.3 \mathrm{a}$ & $66.5 \mathrm{a}$ & 18.95 & 81.05 \\
\hline 11.25 & $6.9 \mathrm{a}$ & $27.0 \mathrm{a}$ & $66.1 \mathrm{a}$ & $4.41^{2}$ & $95.59^{2}$ \\
\hline 22.50 & $11.9 \mathrm{a}$ & $27.9 \mathrm{a}$ & $60.2 \mathrm{a}$ & 17.87 & 82.13 \\
\hline 33.75 & $10.7 \mathrm{a}$ & $25.3 \mathrm{a}$ & $64.0 \mathrm{a}$ & 11.50 & 88.50 \\
\hline 45.00 & $9.1 \mathrm{a}$ & $24.5 \mathrm{a}$ & $66.4 \mathrm{a}$ & 16.16 & 83.84 \\
\hline
\end{tabular}

${ }^{1}$ For relative determination of the adipose and muscle tissues, 1564 intersections for each histological cut were evaluated using the software Image $\mathrm{J}$ (Wayne Rasband, National Institutes of Health, Bethesda, MD).

${ }^{2}$ Differs from the other four dietary treatments described in the column $(\mathrm{P}<0.05)$ by the multiple comparison Nemenyi test.

Means with same letter in the same column are significantly equal to each other $(\mathrm{P}>0.05)$ by the non-parametric Kruskal-Wallis test.
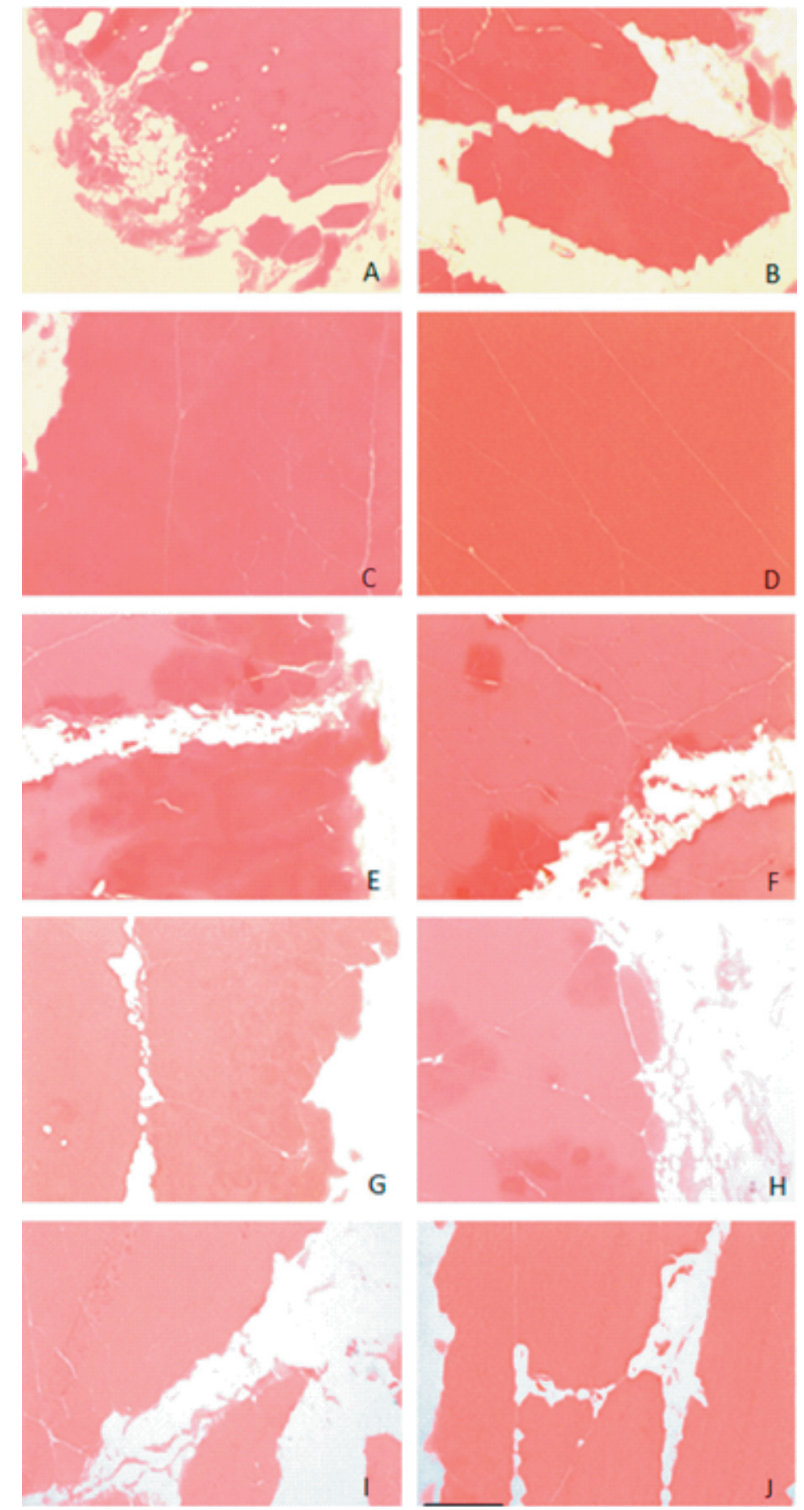

Dietary ractopamine supplementation $\left(\mathrm{mg} \mathrm{kg}^{-1}\right): 0.00$ for $\mathrm{A}$ and $\mathrm{B}, 11.25$ for $\mathrm{C}$ and $\mathrm{D}, 22.50$ for $\mathrm{E}$ and $\mathrm{F}, 33.75$ for $\mathrm{G}$ and $\mathrm{H}$, and 45.00 for $\mathrm{I}$ and $\mathrm{J}$.

Hematoxylin and eosin; $x 10$. Scale bar $=100 \mu \mathrm{m}$.

Cells stained in pink-red color correspond to muscle cells. Places that were not stained correspond to adipose tissue.

Figure 1 - Transverse sections of white skeletal muscle of Piaractus mesopotamicus fed diets supplemented with increasing concentrations of ractopamine.
It is important to emphasize that the results observed in the present experiment can be discussed based on the increasing concentration of dietary ractopamine because all fish showed similar feed intake. The elevation of the serum cortisol level in P. mesopotamicus can be considered a primary biologic response to a stressful situation (Abreu et al., 2009). In turn, this important hormone triggers a series of secondary responses that may alter physiologic and metabolic parameters in pacu (Biller et al., 2008). Therefore, the results of this study indicated that ractopamine can act as a stressor agent culminating in the activation of the hypothalamic-pituitary-interrenal-axis in pacu when the feed is supplemented with $\beta$-adrenergic in concentrations higher than $11.25 \mathrm{mg} \mathrm{kg}^{-1}$ and is provided to animals in the finishing phase during 60 days. Similarly, increased circulating cortisol levels were not noted in finishing pigs fed diets containing $10 \mathrm{mg} \mathrm{kg}^{-1}$ or less of ractopamine (Athayde et al., 2013). There are no scientific reports that explain how and why chronic exposure to high concentrations of dietary ractopamine is recognized by the hypothalamus of teleost fish as a stressor agent and, therefore, this warrants further investigation.

Cortisol is an important steroid hormone, secondary to stress, that increases the availability of oxidizable substrates (Tort, 2011). In relation to lipid metabolism, it has been long known that cortisol along with epinephrine can stimulate lipolysis in adipose tissue (Mommsen et al., 1999). Therefore, in this study, it is likely that the increased level of blood cortisol stimulated lipolysis in the adipose tissue of pacu, resulting in hydrolysis of triacylglycerols into glycerol and fatty acids. Normally, most of the glycerol arising from degradation of acylglycerols stored in adipose tissue is directed through the bloodstream to the liver, where, for example, it can be used as a gluconeogenic precursor (Rui, 2014). It is important to consider that the colorimetric method used in this study to determine the serum triacylglycerol content has glycerol as an 
intermediary substrate. Thus, the largest triacylglycerol value observed in fish fed the diet containing $45.00 \mathrm{mg} \mathrm{kg}^{-1}$ ractopamine may be related to the major release of cortisol, which, in turn, possibly stimulated release of epinephrine. Epinephrine may then have induced lipolysis in the adipose tissue resulting in increase of blood glycerol content, which was quantified colorimetrically.

Although it is ideal to establish comparisons between the same species at the same age, there is no sufficient number of studies on ractopamine use in feeds for pacu, making this degree of comparison difficult at this moment. In this context, Bicudo et al. (2012) reported that juveniles of $P$. mesopotamicus fed diets containing ractopamine concentrations ranging between 10 and $40 \mathrm{mg} \mathrm{kg}^{-1}$ for 60 days did not show any changes in plasma triacylglycerol level. This reinforces the hypothesis that the variation in serum triacylglycerol level in this study is one of the biologic responses triggered by elevation of circulating cortisol level. Furthermore, part of this increase in triacylglycerol level may also be related to lipogenesis inhibition in the liver (indicated by reduction of hepatic lipogenic enzyme activities), which is also triggered by the higher blood cortisol content (Sunny et al., 2002). Thus, since the hepatic lipogenic pathway is inhibited, a higher serum concentration of triacylglycerols is expected.

Although cortisol may have stimulated lipolysis in the adipose tissue (even indirectly by an increased epinephrine concentration), it seems that this effect does not occur for triacylglycerols deposited between the white muscle fibers of pacu because the diet that resulted in higher circulating cortisol level did not decrease fat content in the muscle tissue. However, to have a tissue response to cortisol, it is essential that there are specific intracellular glucocorticoid receptors (Tort, 2011). Thus, a possible explanation for the fact that cortisol stimulates lipolysis in adipose tissue but not in muscle tissue may be that there are distinct distributions of glucocorticoid receptors among cells located in different tissues (Bury et al., 2003; Nesan and Vijayan, 2013).

Most fatty acids originating from triacylglycerol hydrolysis in adipose tissue are associated with the albumin protein for transport in the bloodstream to the liver, where the fatty acids can be metabolized and used according to the needs of the animals (Mersmann, 2002). Therefore, the higher total protein level in pacu fed the diet containing $45.00 \mathrm{mg} \mathrm{kg}{ }^{-1}$ ractopamine may be an indication that these fish had an increased serum albumin concentration in response to the higher content of fatty acid released from lipolysis that was stimulated by cortisol. Moreover, because of its lipophilic character, cortisol needs to bind with proteins such as corticosteroid-binding globulins to be carried within the bloodstream (Lin et al., 2010). This may also have contributed to the increased serum total protein level measured in the P. mesopotamicus in this study.

The NADPH $+\mathrm{H}^{+}$coenzyme is an indispensable reducing agent in lipid biosynthesis (lipogenesis). Therefore, it is possible that the speed of the lipogenic pathway in the liver is reduced whenever the NADPH $+\mathrm{H}^{+}$ concentration in the hepatocyte is lower. The reduced form of this coenzyme is produced from the oxidative step of the pentose-phosphate pathway and from reactions catalyzed by malic enzyme (or NADP-dependent malate dehydrogenase). The glucose 6-phosphate dehydrogenase enzyme catalyzes the irreversible oxidation reaction of glucose 6-phosphate $+\mathrm{NADP}^{+}$to 6-phosphogluconolactone $+\mathrm{NADPH}+\mathrm{H}^{+}$and represents an important regulation point of the pentose-phosphate pathway, while malic enzyme produces NADPH $+\mathrm{H}^{+}$by oxidation of malate to pyruvate. That is why these two enzymes are recognized as lipogenic (Rui, 2014). In this study, the hypothesis that the addition of ractopamine at $45.00 \mathrm{mg} \mathrm{kg}^{-1}$ level contributed directly, in some way, to the reduction of hepatic lipogenic enzyme activity cannot be ruled out. However, when all evaluated parameters are simultaneously analyzed, the results indicate that the reduction in catalytic activity of the glucose 6-phosphate dehydrogenase and malic enzymes was not due to a direct effect of the $\beta$-adrenergic effect, but instead to the blood cortisol elevation, which also inhibited lipogenesis.

Although there are indications that cortisol inhibited hepatic lipogenesis, it seems that this hepatic anabolic pathway is not directly related to the rate of fat deposition between the muscle fibers, since the diet that reduced hepatic lipogenesis did not result in a lower ether extract content in fish fillets. It is accepted that the main tissue for fat reserves in vertebrates is adipose tissue (Peirce et al., 2014). Therefore, it is logical that hepatic lipogenesis inhibition might be more related to triacylglycerol deposition in adipose tissue than in muscle. In this study, the amount of fat stored as adipose tissue (visceral fat, for example) was not measured, because the main objective of this study was to determine which ractopamine concentration promoted a lower ether extract in fillets, which are a cut with great marketing potential as a product for human consumption.

The average ash content determined in pacu fillets in this study was similar to the values reported by Bicudo et al. (2010) and Oliveira et al. (2014), who also determined the chemical composition of $P$. mesopotamicus fillets. Similarly, Bicudo et al., (2012) did not observe differences in crude protein and ash contents in fillet of pacu juveniles fed diets supplemented with ractopamine in concentrations 
of up to $40.00 \mathrm{mg} \mathrm{kg}^{-1}$. In another study, the addition of up to $21 \mathrm{mg} \mathrm{kg}^{-1}$ ractopamine to diets provided to juvenile carp (Cyprinus carpio) also had no effect on protein deposition (Devens et al., 2012). Associating the results observed for fillet yield, crude protein content in the fillet, and the frequency of relative distribution of the muscle fibers, it is possible to infer that the ractopamine levels evaluated did not promote hyperplasic growth (recruitment of new muscle fibers) or hypertrophic growth (increase in muscle fiber diameter) in the fish. For other farm animals in the finishing phase, such as pigs, there are reports that dietary ractopamine improves animal performance (Brumm et al., 2004; Mimbs et al., 2005). However, it is important to emphasize that the growth rate in fish is different from the rate observed for other farm animal groups. While pigs have large weight gain in the finishing phase, most of the fish in the same phase have a minimal growth rate (Johnston, 1999). Other researchers have also reported that the use of dietary ractopamine does not improve the performance of P. mesopotamicus juveniles (Bicudo et al., 2012) or other fish species such as Cyprinus carpio juveniles (Devens et al., 2012) and Oncorhynchus mykiss (Moccia et al., 1998).

Typically, the carcass water content is inversely proportional to the fat deposition in the muscle tissue (Garbossa et al., 2013), which supports the fact that the lowest ether extract level and the highest moisture content were concurrently determined in the fillets of pacu fed dietary ractopamine at $11.25 \mathrm{mg} \mathrm{kg}^{-1}$. Moreover, it was observed in this study that fillets from fish fed dietary ractopamine at $11.25 \mathrm{mg} \mathrm{kg}^{-1}$ had the lowest amount of ether extract as well as less fat deposition between the muscle fibers. These results are important because the current consumer market requires the provision of high-protein, low-fat meat (Fonti-Furnols and Guerrero, 2014). These beneficial effects can be attributed to the direct action of the $\beta$-adrenergic used in the diet, because the serum cortisol level in the fish fed diet containing $11.25 \mathrm{mg} \mathrm{kg}^{-1}$ ractopamine was similar to that determined in fish fed the basal diet without ractopamine. Haji-abadi et al. (2010) also observed a reduction of the fat level in the fillet of Oncorhynchus mykiss fed diet containing $10 \mathrm{mg} \mathrm{kg}^{-1}$ ractopamine and the authors attributed this result to the lipolytic action of ractopamine in the muscle tissue.

When ractopamine binds to the $\beta$-adrenergic receptor, a series of intracellular signaling events that use cyclic AMP as a second messenger occurs and culminates in various cellular responses, which, in turn, promote tissuespecific metabolic and physiologic effects (Mersmann, 1998). An important effect of ractopamine is triggering the phosphorylation process (activation) of hormone-sensitive lipase, which is a key enzyme of the lipolytic pathway
(Mersmann, 2002). Dietary $11.25 \mathrm{mg} \mathrm{kg}^{-1}$ ractopamine may have stimulated lipolysis in the adipose tissue in intensity lower than required to increase the serum glycerol content, and for this reason, the serum triacylglycerol of this experimental group did not increase (because the colorimetric method of analysis for triacylglycerol used in this work also quantifies glycerol). However, this hypothesis cannot be confirmed because lipolytic parameters were not evaluated in the adipose tissue of pacu in this study.

Another important result observed in this study was that when ractopamine was added to the feed in concentrations higher than $11.25 \mathrm{mg} \mathrm{kg}^{-1}$, there was no reduction in fat deposition in $P$. mesopotamicus fillets. This probably occurred because, with prolonged exposure to high concentrations of $\beta$-adrenergic agonists, cyclic AMP activates a protein kinase that phosphorylates the membrane receptor specific for ractopamine, rendering it inactive. Downregulation of $\beta$-adrenergic receptors in the muscle tissue due to chronic exposure to $\beta$-adrenergic agonists has also been reported in previous studies (Smith, 1989; Spurlock et al., 1994; Ferreira et al., 2013). Therefore, supplementation of the diet for 60 days with ractopamine in concentrations higher than $11.25 \mathrm{mg} \mathrm{kg}^{-1}$ is not recommended for pacu in the finishing phase because it probably triggers a downregulation mechanism (or $\beta$ adrenergic receptor desensitization) that affects the ability of the fish to reduce the fat content in muscle tissue.

\section{Conclusions}

Dietary ractopamine promotes metabolic and physiologic responses in a tissue-specific manner in Piaractus mesopotamicus. Muscle growth is not affected by dietary ractopamine; however, the fillet fat content is reduced when fish feed a diet supplemented with $11.25 \mathrm{mg} \mathrm{kg}^{-1}$ ractopamine during the last 60 days of the finishing phase. Moreover, when the supplementation levels of dietary ractopamine are above $11.25 \mathrm{mg} \mathrm{kg}^{-1}$, the serum cortisol level is increased, indicating that high concentration of dietary ractopamine can act as a stressful situation for the pacu.

\section{Acknowledgments}

The authors are grateful to the Fundação de Amparo à Pesquisa do Estado de Minas Gerais (FAPEMIG), the Conselho Nacional de Desenvolvimento Científico e Tecnológico (CNPq), and the Coordenação de Aperfeiçoamento de Pessoal de Nível Superior (CAPES), for their financial support. 


\section{References}

Abreu, J. S.; Takahashi, L. S.; Hoshiba, M. A. and Urbinati, E. C. 2009. Biological indicators of stress in pacu (Piaractus mesopotamicus) after capture. Brazilian Journal of Biology 69:415-421.

Almeida, F. L.; Carvalho, R. F.; Pinhal, D.; Padovani, C. R.; Martins, C. and Dal Pai-Silva, M. 2008. Differential expression of myogenic regulatory factor MyoD in pacu skeletal muscle (Piaractus mesopotamicus Holmberg 1887: Serrasalminae, Characidae, Teleostei) during juvenile and adult growth phases. Micron 39:1306-1311.

Andretta, I.; Kipper, M.; Lehnen, C. R.; Demori, A. B.; Remus, A. and Lovatto, P. A. 2012. Meta-analysis of the relationship between ractopamine and dietary lysine levels on carcass characteristics in pigs. Livestock Science 143:91-96.

AOAC - Association of Official Analytical Chemists. 1990. Official methods of analysis. 15th ed. AOAC International, Arlington, VA.

Athayde, N. B.; Dalla Costa, O. A.; Roça, R. O.; Guidoni, A. L.; Ludtke, C. B.; Oba, E.; Takahira, R. K. and Lima, G. J. M. M. 2013. Stress susceptibility in pigs supplemented with ractopamine. Journal of Animal Science 91:4180-4187.

Barbieri, E. and Bondioli, A. C. V. 2015. Acute toxicity of ammonia in Pacu fish (Piaractus mesopotamicus, Holmberg, 1887) at different temperatures levels. Aquaculture Research 46:565-571.

Bicudo, A. J. A.; Sado, R. Y. and Cyrino, J. E. P. 2010. Growth performance and body composition of Pacu (Piaractus mesopotamicus) (Holmberg 1887) in response to dietary protein and energy levels. Aquaculture Nutrition 16:213-222.

Bicudo, A. J. A.; Sado, R. Y. and Cyrino, J. E. P. 2012. Growth, body composition and hematology of juvenile pacu (Piaractus mesopotamicus) fed increasing levels of ractopamine. Arquivo Brasileiro de Medicina Veterinária e Zootecnia 64:1335-1342.

Biller, J. D.; Bendhack, F.; Takahashi, L. S. and Urbinati, E. C. 2008. Stress responses in juvenile pacu (Piaractus mesopotamicus) submitted to repeated air exposure. Acta Scientiarum. Animal Sciences 30:89-93.

Boler, D. D.; Shreck, A. L.; Faulkner, D. B.; Killefer, J.; McKeith, F. K.; Homm, J. W. and Scanga, J. A. 2012. Effect of ractopamine hydrochloride (Optaflexx) dose on live animal performance, carcass characteristics and tenderness in early weaned beef steers. Meat Science 92:458-463.

Boscolo, W. R.; Signor, A.; Freitas, J. M. A.; Bittencourt, F. and Feiden, A. 2011. Nutrição de peixes nativos. Revista Brasileira de Zootecnia 40(supl. especial):145-154.

Bradford, M. M. 1976. A rapid and sensitive method for the quantitation of microgram quantities of protein utilizing the principle of proteindye binding. Analytical Biochemistry 72:248-254.

Brumm, M. C.; Miller, P. S. and Thaler, R. C. 2004. Response of barrows to space allocation and ractopamine. Journal of Animal Science 82:3373-3379.

Bury, N. R.; Sturm, A.; Le Rouzic, P.; Lethimonier, C.; Ducouret, B.; Guiguen, Y.; Robinson-Rechavi, M.; Laudet, V.; Rafestin-Oblin, M. E. and Prunet, P. 2003. Evidence for two distinct functional glucocorticoid receptors in teleost fish. Journal of Molecular Endocrinology 31:141-156.

Devens, M. A.; Lazzari, R.; Rotilli, D. A.; Pucci, L. E. A.; Veiverberg, C. A. and Coldebella, I. J. 2012. Ractopamin in the diet of Hungarian Carp (Cyprnus carpio) reared in net cages. Ractopamina na dieta da carpa húngara (Cyprnus carpio) criada em tanques-rede. Arquivo Brasileiro de Medicina Veterinária e Zootecnia 64:1717-1722.

Dubowitz, V.; Sewry, C. A.; Oldfors, A. and Lane, R. 2013. Histological and histochemical changes. p.55-94. In: Muscle biopsy: a practical approach. Dubowitz, V.; Sewry, C. A. and Oldfors, A., eds. Saunders, London.

Edmonds, M. S. and Baker, D. H. 2010. Effect of dietary protein and lysine fluctuations in the absence and presence of ractopamine on performance and carcass quality of late-finishing pigs. Journal of Animal Science 88:604-611.

FAO - Food and Agriculture Organization of the United Nations. 2014 The State of World Fisheries and Aquaculture: Opportunities and challenges. Roma, Italy. 223p.

Ferreira, M. S. S.; Garbossa, C. A. P.; Oberlender, G.; Pereira, L. J.; Zangeronimo, M. G.; Sousa, R. V. and Cantarelli, V. S. 2013. Effect of ractopamine on lipid metabolism in vivo - a systematic review. Brazilian Archives of Biology and Technology 56:35-43.

Font-i-Furnols, M. and Guerrero, L. 2014. Consumer preference, behavior and perception about meat and meat products: An overview. Meat Science 98:361-371.

Garbossa, C. A. P.; Sousa, R. V.; Cantarelli, V. S.; Pimenta, M. E. S. G.; Zangeronimo, M. G.; Silveira, H.; Kuribayashi, T. H. and Cerqueira, L. G. S. 2013. Ractopamine levels on performance, carcass characteristics and quality of pig meat. Revista Brasileira de Zootecnia 42:325-333.

Gerlemann, G. D.; Allee, G. L.; Rincker, P. J.; Ritter, M. J.; Boler, D. D. and Carr, S. N. 2014. Impact of ractopamine hydrochloride on growth, efficiency, and carcass traits of finishing pigs in a three-phase marketing strategy. Journal of Animal Science 92:1200-1207.

Graeve, K.; von Schaewen, A. and Scheibe, R. 1994. Purification, characterization, and cDNA sequence of glucose-6-phosphate dehydrogenase from potato (Solanum tuberosum L.). The Plant Journal 5:353-361.

Haji-abadi, S. M. A. J.; Soofiani, N. M.; Sadeghi, A. A.; Chamani, M. and Riazi, G. H. 2010. Effects of supplemental dietary L-carnitine and ractopamine on the performance of juvenile rainbow trout, Oncorhynchus mykiss. Aquaculture Research 41:1582-1591.

Holmberg, E. L. 1887. Viaje á misiones. Boletin de la Academia Nacional de Ciencias en Córdoba 10:5-391.

Johnston, I. A. 1999. Muscle development and growth: potential implication for flesh quality in fish. Aquaculture 177:99-115.

Jomori, K.; Carneiro, D. J.; Martins, I. E. G. and Portella, M. C. 2005. Economic evaluation of Piaractus mesopotamicus juvenile production in different rearing systems. Aquaculture 243:175-183.

Kill, J. L.; Haddade, I. R.; Santos Júnior, I. C.; Haese, D.; Chambela Neto, A.; Paulino, P. V. R. and D'ávila Possatti, C. 2015. Ractopamine hydrochloride on performance and carcass traits of confined Nellores cattle. Ciência Rural 45:1830-1834.

Lin, H.; Muller, Y. A. and Hammond, G. L. 2010. Molecular and structural basis of steroid hormone binding and release from corticosteroid-binding globulin. Molecular and Cellular Endocrinology 316:3-12.

Mersmann, H. J. 2002. Beta-adrenergic receptor modulation of adipocyte metabolism and growth. Journal of Animal Science 80: E24-E29.

Mersmann, H. J. 1998. Overview of the effects of $\beta$-adrenergic receptor agonists on animal growth including mechanisms of action. Journal of Animal Science 76:160-172.

Mimbs, K. J.; Pringle, T. D.; Azain, M. J.; Meers, S. A. and Armstrong, T. A. 2005. Effects of ractopamine on performance and composition of pigs phenotypically sorted into fat and lean groups. Journal of Animal Science 83:1361-1369.

Mitchell, A. D.; Solomon, M. B. and Steele, N. C. 1990. Response of low and high protein select lines of pigs to the feeding of the beta-adrenergic agonist ractopamine (phenethanolamine). Journal of Animal Science 68:3226-3232.

Moccia, R. D.; Gurure, R. M.; Atkinson, J. L. and Vandenberg, G. W. 1998. Effects of the repartitioning agent ractopamine on the 
growth and body composition of rainbow trout, Oncorhynchus mykiss (Walbaum), fed three levels of dietary protein. Aquaculture Research 29:687-694.

Mommsen, T. P.; Vijayan, M. M. and Moon, T. W. 1999. Cortisol in teleosts: dynamics, mechanisms of action, and metabolic regulation. Reviews in Fish Biology and Fisheries 9:211-268.

Nesan, D. and Vijayan, M. M. 2013. The transcriptomics of glucocorticoid receptor signaling in developing zebrafish. PLoS One 8:e80726.

Niño, A. M. M.; Granja, R. H. M. M.; Wanschel, A. C. B. A. and Salerno, A. G. 2017. The challenges of ractopamine use in meat production for export to European Union and Russia. Food Control 72:289-292.

Oliveira, L. M. F. S.; Leal, R. S.; Mesquita, T. C.; Pimenta, M. E. S. G.; Zangeronimo, M. G.; Sousa, R. V. and Alvarenga, R. R. 2014. Effect of ractopamine on the chemical and physical characteristics of pacu (Piaractus mesopotamicus) steaks. Arquivo Brasileiro de Medicina Veterinária e Zootecnia 66:185-194.

Peirce, V.; Carobbio, S. and Vidal-Puig, A. 2014. The different shades of fat. Nature 510:76-83.

Ribeiro, P. A. P.; Costa, L. S.; Pereira, R. T.; Murgas, L. D. S. and Rosa, P. V. 2013. Metabolic parameters of pacu fed different oil sources. Pesquisa Agropecuária Brasileira 48:1035-1042.

Rui, L. 2014. Energy metabolism in the liver. Comprehensive Physiology 4:177-197.
Smith, C. K. 1989. Affinity of phenethanolamines for skeletal muscle beta-adrenergic receptors and influence on receptor downregulation. Journal of Animal Science 67:190.

Spina Junior, J.; Bright, H. J. and Rosenbloom, J. 1970. Purification and properties of L-malic enzyme from Escherichia coli. Biochemistry 9:3794-3801.

Spurlock, M. E.; Cusumano, J. C.; Ji, S. Q.; Anderson, D. B.; Smith, C. K.; Hancock, D. L. and Mills, S. E. 1994. The effect of ractopamine on beta-adrenoceptor density and affinity in porcine adipose and skeletal muscle tissue. Journal of Animal Science 72:75-80.

Sunny, F.; Lakshmy, P. S. and Oommen, O. V. 2002. Rapid action of cortisol and testosterone on lipogenic enzymes in a fresh water fish Oreochromis mossambicus: short-term in vivo and in vitro study. Comparative Biochemistry and Physiology Part B 131:297-304.

Tort, L. 2011. Stress and immune modulation in fish. Developmental and Comparative Immunology 35:1366-1375.

Urbinati, E. C. and Gonçalves, F. D. 2005. Pacu (Piaractus mesopotamicus). p.225-246. In: Native species for fish farming in Brazil. Espécies nativas para piscicultura no Brasil. Baldisseroto, B. and Gomes, L. C., eds. UFSM, Santa Maria.

Venturini, F. P.; Moraes, F. D.; Cortella, L. R. X.; Rossi, P. A.; Cruz, C. and Moraes, G. 2015. Metabolic effects of trichlorfon (Masoten ${ }^{\circledR}$ ) on the neotropical freshwater fish pacu (Piaractus mesopotamicus). Fish Physiology and Biochemistry 41:299-309. 